DOI: 10.17707/AgricultForest.63.1.24

\author{
Ilija RISTESKI, \\ Karolina KOČOSKA, Valentina PELIVANOSKA ${ }^{1}$
}

\title{
RESULTS OF INVESTIGATIONS OF GENOTYPE AND ITS INFLUENCE ON THE YIELD, QUALITY AND ECONOMIC EFFECT OF VIRGINIA TOBACCO IN R. MACEDONIA
}

\begin{abstract}
SUMMARY
Investigations were carried out in 2014 and 2015 on the experimental field of the Scientific Tobacco Institute - Prilep. They included four introduced fertile varieties and three domestic promising hybrid lines in CMS form created in the Institute, with the standard Australian variety Ca-757 used as a check. The trial was set up in randomized blocks with 4 replications. The highest average yield per stalk $(161,7 \mathrm{~g})$ and per hectare $(3593 \mathrm{~kg})$ was achieved in line V$79 / 09 \mathrm{CMS} \mathrm{F}_{1}$. The lowest yield per stalk $(125,3 \mathrm{~g})$ and hectare $(2784 \mathrm{~kg})$ was recorded in the standard Australian variety Ca-757.

The highest quality of tobacco raw, expressed through the average price, was obtained in the line V-79/09 CMS F $\mathrm{F}_{1}(1,51 \mathrm{USD} / \mathrm{kg})$ and lowest in the variety Ca-757 (1,28 USD/kg). Also, the gross income was the highest in line V$79 / 09 \mathrm{CMS} \mathrm{F}_{1}$ (5 $434 \mathrm{USD} / \mathrm{ha}$ ) and the lowest in the variety Ca-757 (3 583 $\mathrm{USD} / \mathrm{kg}$ ).

With some variety lines, for some characteristics, there were statistically significant differences with 5\% and 1\% significant levels compared to a Ca-757.

Keywords: tobacco, Virginia, yield, income.
\end{abstract}

\section{INTRODUCTION}

The raw material of Virginia tobacco is inevitable component in the manufacturing of blended cigarettes. According to Beljo (1996) and Uzunoski (1985), Virginia belongs to the group of large-leaf, high tobaccos $(200 \mathrm{~cm})$. Its growth and development requires precisely determined agro-ecological conditions and cultural practices, and specific way of curing (flue-cured). This tobacco was grown in certain regions of the Republic of Macedonia until 2002, after which the production has stopped and now Macedonian cigarette factories is fully dependent on imports of this type. To overcome this situation it is necessary to restart the production according to world standards and to create raw material similar or equal to the imported one. In production chain of Virginia tobacco, variety is a very important factor which has a large impact on yield and quality of

\footnotetext{
${ }^{1}$ Ilija Risteski, (corresponding author: ilija.r@t.mk), Karolina Kočoska, Department of genetics, selection and seed control, Scientific Tobacco Institute - Prilep, Kičevska bb, Prilep, MACEDONIA, Valentina Pelivanoska, Department of agrotechnics, Scientific Tobacco Institute Prilep, Kičevska bb, Prilep, MACEDONIA

Notes: The authors declare that they have no conflicts of interest. Authorship Form signed online.
} 
the raw material. In recent years, many hybrid varieties (lines) in CMS form have been created in Tobacco Institute - Prilep. The results of comparative trials show that this newly created varieties and (lines) might be also interesting for tobacco growers.

\section{MATERIAL AND METHODS}

Six varieties, four of them in fertile form, were used as material for work: Ca-757 was used as a check, Vissana (Australia), V-3816 (Bulgaria), V-36/13 (Macedonia) and the male-sterile hybrid lines V-99/11 CMS F $F_{1}$ and V$79 / 09$ CMS F $_{1}$ created in Tobacco Institute - Prilep. The trial was set up on colluvial soil in randomized block system with four replications at $90 \times 50 \mathrm{~cm}$ planting density, on previously prepared site (one autumn and two spring ploughings, fertilization with $300 \mathrm{~kg} / \mathrm{ha}$ NPK 8:22:20 and application of herbicide). Before the second hoeing, manual feeding of stalks was made with 3 g/stalk 26\% KAN. The plants were also treated with chemicals for their protection from pests and diseases. Harvested tobacco was stringed, yellowed and then dried. Qualitative assessment of cured tobacco was made according to the rules for assessment of quality of dry Virginia tobacco (Rules on criteria for qualitative and quantitative assessment of raw tobacco leaves "Official Gazette" of R. Macedonia, No. 16/2007, amended and supplemented No. 144/2010 and No. 20/2011). Corrected yield per stalk and hectare was calculated by the method of Rimker and the gross income (USD/ha) by multiplying yield per hectare and the average price of $1 \mathrm{~kg}$ raw tobacco. Conversion in USD was calculated by 2015 average middle exchange rate of National Bank of Republic of Macedonia (50,65 ден for 1 USD).The results were statistically processed using the analysis of variance and LSD test.

\section{RESULTS AND DISCUSSION}

Tobacco yield mainly depends on leaves, their number and size. This trait is genetically controlled in each variety (genotype), but it is also highly affected by the environmental conditions during the growing season. Dražič (1986) explains that the yield is directly influenced by the genotype and environment. Carriers of the yield and quality of raw material in Virginia tobacco are the middle belt leaves, their size and color obtained after curing. According to Beljo (1996), tobacco yield and quality also depend on cultural practices applied during the growing season (fertilization, irrigation, harvesting time, yellowing, curing etc.). Results of our investigation of the above traits are presented in Tables 1, 2, 3 and 4.

\section{Yield per stalk, g/stalk}

Data on the obtained yield per stalk from the investigated varieties and lines are presented in Table 1 .

According to data, the highest average yield per stalk was recorded in line V-79/09 CMS $F_{1}(161,7 \mathrm{~g})$ and the lowest in the check variety Ca-757 (125,3 g). In other varieties in the trial, the average yield per stalk ranged from 135,8 $\mathrm{g}$ in 
variety $\mathrm{V}-3816$, to $141,3 \mathrm{~g}$ in line $\mathrm{V}-99 / 11 \mathrm{CMS} \mathrm{F}_{1}$. It can be also noted that higher yields were achieved in the more humid conditions of 2014. In both years of investigation, only the variety $\mathrm{V}-79 / 09 \mathrm{CMS} \mathrm{F}_{1}$, achieved statistical significance at $1 \%$ level compared to the check. The line V-99/11 CMS F achieved statistical significance at 1\% level compared to the check only in 2015 . The variety Vissana in 2014 showed statistical significance at 5\% level.

Table 1. Corrected yield per stalk (g/stalk)

\begin{tabular}{|c|c|c|c|c|c|c|}
\hline \multirow{2}{*}{ Variety } & \multirow{2}{*}{ Year } & \multirow{2}{*}{ g/stalk } & \multirow{2}{*}{$\begin{array}{c}\text { Average } \\
2014 / 2015 \\
\text { g/stalk }\end{array}$} & \multicolumn{3}{|c|}{ Difference } \\
\hline & & & & Absolute & Relative & Rank \\
\hline \multirow{2}{*}{ Ca-757 Ø } & 2014 & 125,25 & \multirow{2}{*}{125,3} & \multirow{2}{*}{ I } & \multirow{2}{*}{100,00} & \multirow{2}{*}{6} \\
\hline & 2015 & 125,34 & & & & \\
\hline \multirow{2}{*}{ Vissana } & 2014 & $148,80^{+}$ & \multirow{2}{*}{140,3} & \multirow{2}{*}{$+15,0$} & \multirow{2}{*}{111,97} & \multirow{2}{*}{3} \\
\hline & 2015 & 131,87 & & & & \\
\hline \multirow{2}{*}{ V-3816 } & 2014 & 135,28 & \multirow{2}{*}{135,8} & \multirow{2}{*}{$+10,5$} & \multirow{2}{*}{108,38} & \multirow{2}{*}{5} \\
\hline & 2015 & 136,31 & & & & \\
\hline \multirow{2}{*}{ V-36/13 } & 2014 & 143,62 & \multirow{2}{*}{137,4} & \multirow{2}{*}{$+12,1$} & \multirow{2}{*}{109,66} & \multirow{2}{*}{4} \\
\hline & 2015 & 131,15 & & & & \\
\hline \multirow{2}{*}{ V-99/11 CMS F } & 2014 & 141,12 & \multirow{2}{*}{141,3} & \multirow{2}{*}{$+16,0$} & \multirow{2}{*}{112,76} & \multirow{2}{*}{2} \\
\hline & 2015 & $141,50^{++}$ & & & & \\
\hline \multirow{2}{*}{ V-79/09 CMS F } & 2014 & $162,41^{++}$ & \multirow{2}{*}{161,7} & \multirow{2}{*}{$+36,4$} & \multirow{2}{*}{129,05} & \multirow[b]{2}{*}{1} \\
\hline & 2015 & $160,97^{++}$ & & & & \\
\hline
\end{tabular}

\begin{tabular}{|c|c|c|c|c|c|c|c|c|}
\hline \multirow{2}{*}{ LSD } & \multirow{2}{*}{2014} & $5 \%^{+}$ & $=$ & $19,15 \mathrm{~g} / \mathrm{stalk}$ & \multirow{2}{*}{2015} & $5 \%^{+}$ & & $5,91 \mathrm{~g} / \mathrm{stalk}$ \\
\hline & & $1 \%{ }^{++}$ & $=$ & $26,57 \mathrm{~g} / \mathrm{stalk}$ & & $1 \%{ }^{++}$ & $=$ & $8,19 \mathrm{~g} / \mathrm{sta}$ \\
\hline
\end{tabular}

Dražič et al. (2012) made investigations with 13 domestic and introduced varieties and lines in 2011 at various locations in Serbia and found that the yield per stalk ranged from $105 \mathrm{~g} / \mathrm{stalk}$ to $257 \mathrm{~g} / \mathrm{stalk}$ in Nova Pazova and from 101 g/stalk to $298 \mathrm{~g} / \mathrm{stalk}$ in Starčevo. Risteski (1999) reported that the stalks of MV1,grown at nutritional area of $0,25 \mathrm{~m}^{2}$ achieved an average yield of 79,7 $\mathrm{g} / \mathrm{stalk}$ and those grown at $1 \mathrm{~m}^{2}$ achieved 198,2 $\mathrm{g}$.

\section{Yield per hectare, $\mathrm{kg} / \mathrm{ha}$}

Data on the obtained yield per hectare are presented in Table 2.

Data reveals a very close relationship between yield per stalk and per hectare. The highest average yield was obtained in line V-79/09 CMS F 13593 $\mathrm{kg} / \mathrm{ha}$ ) and the lowest in check variety Ca-757 (2 $784 \mathrm{~kg} / \mathrm{ha})$. In other varieties investigated, the yield ranged from $3017 \mathrm{~kg} / \mathrm{ha}$ in variety V-3816 to $3140 \mathrm{~kg} / \mathrm{ha}$ in line V-99/11 CMS $F_{1}$. In 2014 and 2015, statistical a significant difference at $1 \%$ wasachieved only the line V-79/09 CMS $F_{1}$. Difference like this in 2015 was achieved by line V-99/11 CMS $\mathrm{F}_{1}$, and variety V-3816. In 2014 and 2015, variety Vissana achieved statistically significant differences at 5\% level. 
Table 2. Corrected yield per hectare $(\mathrm{kg} / \mathrm{ha})$

\begin{tabular}{|c|c|c|c|c|c|c|}
\hline \multirow{2}{*}{ Variety } & \multirow{2}{*}{ Year } & \multirow{2}{*}{ kg/ha } & \multirow{2}{*}{$\begin{array}{c}\text { Average } \\
2014 / 2015 \\
\text { kg/ha }\end{array}$} & \multicolumn{3}{|c|}{ Difference } \\
\hline & & & & Absolute & Relative & Rank \\
\hline \multirow{2}{*}{ Ca-757 Ø } & 2014 & 2.783 & \multirow{2}{*}{2.784} & \multirow{2}{*}{ I } & \multirow{2}{*}{100,00} & \multirow{2}{*}{6} \\
\hline & 2015 & 2.785 & & & & \\
\hline \multirow{2}{*}{ Vissana } & 2014 & $3.306^{+}$ & \multirow{2}{*}{3.118} & \multirow{2}{*}{+334} & \multirow{2}{*}{111,99} & \multirow{2}{*}{3} \\
\hline & 2015 & $2.931^{+}$ & & & & \\
\hline \multirow{2}{*}{ V-3816 } & 2014 & 3.006 & \multirow{2}{*}{3.017} & \multirow{2}{*}{+233} & \multirow{2}{*}{108,37} & \multirow{2}{*}{5} \\
\hline & 2015 & $3.029^{++}$ & & & & \\
\hline \multirow{2}{*}{ V-36/13 } & 2014 & 3.191 & \multirow{2}{*}{3.052} & \multirow{2}{*}{+268} & \multirow{2}{*}{109,63} & \multirow{2}{*}{4} \\
\hline & 2015 & 2.914 & & & & \\
\hline \multirow{2}{*}{ V-99/11 CMS F } & 2014 & 3.136 & \multirow{2}{*}{3.140} & \multirow{2}{*}{+356} & \multirow{2}{*}{112,78} & \multirow{2}{*}{2} \\
\hline & 2015 & $3.144^{++}$ & & & & \\
\hline \multirow{2}{*}{ V-79/09 CMS F 1} & 2014 & $3.609^{++}$ & \multirow{2}{*}{3.593} & \multirow{2}{*}{+809} & \multirow{2}{*}{129,05} & \multirow{2}{*}{1} \\
\hline & 2015 & $3.577^{++}$ & & & & \\
\hline \multirow{2}{*}{ LSD } & $=$ & 425,48 & \multirow{2}{*}{2015} & \multirow{2}{*}{$\begin{array}{l}5 \%^{+}= \\
1 \%^{++}=\end{array}$} & 131,23 & $\mathrm{~g} / \mathrm{ha}$ \\
\hline & $=$ & 589,28 & & & 181,75 & $\mathrm{~g} / \mathrm{ha}$ \\
\hline
\end{tabular}

Jovovič (1957) stated that according to the results of tests performed and the experimental field of Bar (Montenegro) in the fifties of the last century, the yield per hectare of type Virginia was $1707 \mathrm{~kg} / \mathrm{ha}$. Devčič et al. (1982) reported that by application of good cultural practices, Croatian hybrid varieties $\mathrm{H}-30, \mathrm{H}-$ 31 and H-32 can reach over $2000 \mathrm{~kg} / \mathrm{ha}$. Hawks (1978) presented the yields of Virginia tobacco in the United States in different periods of time. According to the data, the average yield in the period 1934-1938 was only $959 \mathrm{~kg} / \mathrm{ha}$ and in 1964-1967 it increased to $2224 \mathrm{~kg} / \mathrm{ha}$. Risteski et al. (2012) reported that higher yields were achieved in Virginia tobacco lines created in the Scientific Tobacco Institute - Prilep, reaching up to $3549 \mathrm{~kg} / \mathrm{h}$ a in line V-53 CMS $\mathrm{F}_{1}$.

\section{Average price, USD/kg}

The quality of tobacco raw expressed in monetary value gives the average price per kg. It is closely related to the variety, proper and timely applied cultural practices, yellowing, curing, etc. Data on average price in the varieties investigated are presented in Table 3 . According to the above data, the average price ranged from $1,28 \mathrm{USD} / \mathrm{kg}$ in check variety $\mathrm{Ca}-757$ to $1,51 \mathrm{USD} / \mathrm{kg}$ in line V-79/09 CMS F

In the other varieties and lines, the average price ranged from $1,33 \mathrm{USD} / \mathrm{kg}$ in variety $\mathrm{V}-36 / 13$ to $1,46 \mathrm{USD} / \mathrm{kg}$ in line V-99/11 CMS F $\mathrm{F}_{1}$. Statistically significant differences at $1 \%$ level in both years of investigation were observed only in line V-79/09 CMS $F_{1}$. Statistical significance differences at $1 \%$ level in 2014 and 2015, was achieved only by the line V-79/09 CMS F . 
Table 3. Average price (USD/kg)

\begin{tabular}{|c|c|c|c|c|c|c|}
\hline \multirow{2}{*}{ Variety } & \multirow{2}{*}{ Year } & \multirow{2}{*}{ USD/kg } & \multirow{2}{*}{$\begin{array}{c}\text { Average } \\
\text { 2014/2015 } \\
\text { USD/kg }\end{array}$} & \multicolumn{3}{|c|}{ Difference } \\
\hline & & & & Absolute & Relative & Rank \\
\hline \multirow{2}{*}{ Ca-757 Ø } & 2014 & 1,25 & \multirow{2}{*}{1,28} & \multirow{2}{*}{ / } & \multirow{2}{*}{100,00} & \multirow{2}{*}{6} \\
\hline & 2015 & 1,32 & & & & \\
\hline \multirow{2}{*}{ Vissana } & 2014 & 1,31 & \multirow{2}{*}{1,35} & \multirow{2}{*}{$+0,07$} & \multirow{2}{*}{105,45} & \multirow{2}{*}{3} \\
\hline & 2015 & 1,39 & & & & \\
\hline \multirow{2}{*}{ V-3816 } & 2014 & 1,32 & \multirow{2}{*}{1,34} & \multirow{2}{*}{$+0,06$} & \multirow{2}{*}{104,60} & \multirow{2}{*}{4} \\
\hline & 2015 & 1,36 & & & & \\
\hline \multirow{2}{*}{ V-36/13 } & 2014 & 1,31 & \multirow{2}{*}{1,33} & \multirow{2}{*}{$+0,05$} & \multirow{2}{*}{103,90} & \multirow{2}{*}{5} \\
\hline & 2015 & 1,35 & & & & \\
\hline \multirow{2}{*}{ V-99/11 CMS F 1} & 2014 & $1,48^{++}$ & \multirow{2}{*}{1,46} & \multirow{2}{*}{$+0,18$} & \multirow{2}{*}{114,06} & \multirow{2}{*}{2} \\
\hline & 2015 & $1,44^{+}$ & & & & \\
\hline \multirow{2}{*}{ V-79/09 CMS F } & 2014 & $1,51^{++}$ & \multirow{2}{*}{1,51} & \multirow{2}{*}{$+0,23$} & \multirow{2}{*}{117,96} & \multirow{2}{*}{1} \\
\hline & 2015 & $1,51^{++}$ & & & & \\
\hline \multirow{2}{*}{ LSD } & $=$ & 0,11 & \multirow{2}{*}{2015} & $5 \%+$ & \multicolumn{2}{|c|}{$0,11 \mathrm{USD} / \mathrm{kg}$} \\
\hline & $=$ & $0,15 \mathrm{~L}$ & & $1 \%{ }^{++}$ & $0,15_{1}$ & $\mathrm{SD} / \mathrm{kg}$ \\
\hline
\end{tabular}

The line V-99/11 CMS F1 achieved statistical significant difference at $1 \%$ in 2014, and in 2015 achieved statistical significant difference at 5\%. Kočoska et al. (2004) in investigations with six varieties and lines in the region of Prilep during 2002 and 2003 reported that the highest average price was achieved in line V-53 (1,30 USD/kg) and the lowest in line V-69 (1,13 USD/kg).

Table 4. Gross income (USD/ha)

\begin{tabular}{|c|c|c|c|c|c|c|}
\hline \multirow{2}{*}{ Variety } & \multirow{2}{*}{ Year } & \multirow{2}{*}{ USD/ha } & \multirow{2}{*}{$\begin{array}{c}\text { Average } \\
\text { 2014/2015 } \\
\text { USD/ha }\end{array}$} & \multicolumn{3}{|c|}{ Difference } \\
\hline & & & & Absolute & Relative & Rank \\
\hline \multirow{2}{*}{ Ca-757 Ø } & 2014 & 3488 & \multirow{2}{*}{3583} & \multirow{2}{*}{ - } & \multirow{2}{*}{100,00} & \multirow{2}{*}{6} \\
\hline & 2015 & 3678 & & & & \\
\hline \multirow{2}{*}{ Vissana } & 2014 & $4334^{+}$ & \multirow{2}{*}{4200} & \multirow{2}{*}{+617} & \multirow{2}{*}{117,22} & \multirow{2}{*}{3} \\
\hline & 2015 & 4067 & & & & \\
\hline \multirow{2}{*}{ V-3816 } & 2014 & 3976 & \multirow{2}{*}{4048} & \multirow{2}{*}{+465} & \multirow{2}{*}{112,98} & \multirow{2}{*}{5} \\
\hline & 2015 & $4121^{+}$ & & & & \\
\hline \multirow{2}{*}{ V-36/13 } & 2014 & $4175^{+}$ & \multirow{2}{*}{4053} & \multirow{2}{*}{+470} & \multirow{2}{*}{113,12} & \multirow{2}{*}{4} \\
\hline & 2015 & 3932 & & & & \\
\hline \multirow{2}{*}{$\underset{F_{1}}{\text { V-99/11 CMS }}$} & 2014 & $4641^{++}$ & \multirow{2}{*}{4591} & \multirow{2}{*}{+1008} & \multirow{2}{*}{128,13} & \multirow{2}{*}{2} \\
\hline & 2015 & $4541^{++}$ & & & & \\
\hline \multirow{2}{*}{$\begin{array}{c}\mathrm{V}-79 / 09 \mathrm{CMS} \\
\mathrm{F}_{1} \\
\end{array}$} & 2014 & $5446^{++}$ & \multirow{2}{*}{5434} & \multirow{2}{*}{+1851} & \multirow{2}{*}{151,66} & \multirow[b]{2}{*}{1} \\
\hline & 2015 & $5422^{++}$ & & & & \\
\hline \multirow{2}{*}{ LSD } & $=$ & USD & \multirow{2}{*}{2015} & \multirow{2}{*}{$\begin{array}{l}5 \%^{+} \\
1 \%++\end{array}$} & USD/ & \\
\hline & $=$ & 909 USL & & & USD/1 & \\
\hline
\end{tabular}




\section{Gross income, USD/ha}

The data presented in Table 4 determine the average price per $1 \mathrm{~kg}$ of raw tobacco and yield per hectare achieved by the investigated varieties and lines. Compared to the check variety Ca-757 (3 583 USD/ha), the highest gross income was recorded in line V-79/09 CMS F $15434 \mathrm{USD} / \mathrm{ha}$ ). In other varieties and lines, gross income ranged from $4048 \mathrm{USD} / \mathrm{ha}$ in V-3816 to $4591 \mathrm{USD} / \mathrm{ha}$ in line V-99/11 CMS F .

In the both years of investigation (2014 and 2015) statistical significant difference at $1 \%$ level, were achieved by the lines V-79/09 CMS $\mathrm{F}_{1}$ and V99/11 CMS $F_{1}$. In 2014 variety Vissana and the line V-3613 achieved statistical significant difference at 5\% level, and in 2015 the variety V-3816 also achieved statistical significant difference at $5 \%$ level.

\section{CONCLUSIONS}

The highest average yield per hectare and stalk was recorded in line V$79 / 09 \mathrm{CMS} \mathrm{F}_{1}(161,7 \mathrm{~g} / \mathrm{stalk}$ and $3593 \mathrm{~kg} / \mathrm{ha})$ and the lowest in variety Ca-757 $(125,3 \mathrm{~g} / \mathrm{stalk}$ and $2784 \mathrm{~kg} / \mathrm{ha})$. The highest average price of raw tobacco was achieved in line V-79/09 CMS $F_{1}(1,51 \mathrm{USD} / \mathrm{kg})$ and the lowest in variety Ca$757(1,28 \mathrm{USD} / \mathrm{kg})$.The highest gross income was obtained in line V$79 / 09 \mathrm{CMS} \mathrm{F}_{1}$ (5 $434 \mathrm{USD} / \mathrm{ha}$ ), and the lowest in variety Ca-757 (3 583 USD/ha). The above data lead to a conclusion that genotype has high influence on the investigated traits and therefore more attention should be paid to the selection of varieties for mass production.

\section{REFERENCES}

Beljo J., 1996. Postupak za identifikaciju kultivara duhana. Izvješče o znanstvenom i stručnom radu u 1994 god. Duhanski institut - Zagreb.

Devčič K., Triplat J. 1982. Neka svojstva novih flue-cured sorti uzgajanih u Duhanskom institute - Zagreb. Тутун/Tobacco, XXXII, N ${ }^{0} 11-12,5-10$

Dražič S. 1986. Prilog proučavanju nasledjivanja kvantitativnih stvojstava duvana. Univezitet u Beogradu - Poljoprivredni fakultet - Doktorska disertacija.

Jovovič V. 1957. Neki američki tipovi duvana i mogučnost njihovog gajenja na crnogorskom primorju. Agriculure and forestry: 3,4: 59-68

Hawks S.N., 1978. Osnovi proizvodnje virginiskog duhana. Zagreb (translation)

Кочоска К., Ристески И., Димитриески М., Мицеска Г. 2004. Компаративни испитувања на некои новосоздадени вирџиниски сорти тутун. 60 год. Юбилей на научна конференция с международно участие. Стр. 162-167. Пловдив

Ристески И. 1999. Корелација помеѓу хранливата површина и некои производнотехнолошки својства на тутунот од сортата вирџинија МВ-1. Магистерски труд. Земјоделски факултет. Скопје

Risteski I., Kocoska K. 2012. Results of broadleaf tobacco breeding in Scientific tobacco institute - Prilep. International symposium on agriculture and food. 12-14 Dec. 2012. Skopje. Republic of Macedonia. p. 643-648.

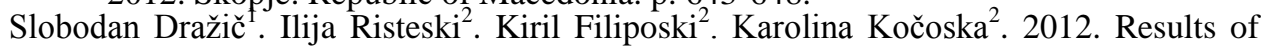
studies on recently developed virginia tobacco genotypes under different growing conditions in Serbia. Тутун/Tobacco. Vol. 62, $\mathrm{N}^{\mathrm{O}} 1-6$, p.03-08

Филипоски К. 2011. Статистички методи во земјоделските истражувања - одбрани поглавја. Научен институт за тутун - Прилеп. 